J Cell Physiol. 2010 March ; 222(3): 540-545. doi:10.1002/jcp.21993.

\title{
Genomic Organization of microRNAs
}

\author{
Abigail F. Olena and James G. Patton * \\ Department of Biological Sciences, Vanderbilt University, Nashville, Tennessee
}

\begin{abstract}
microRNAs (miRNAs) are small ( $22 \mathrm{nt}$ ) noncoding RNAs that have been shown to regulate gene expression post-transcriptionally. They function by pairing with the $3^{\prime}$ UTR of target mRNAs and repressing translation or by targeting the mRNA for degradation. miRNAs are involved in diverse aspects of development, maintenance, and disease, and are largely evolutionarily conserved in metazoans. Searching the genomes of organisms from viruses to worms to humans has revealed potentially thousands of miRNA genes. Understanding the patterns of genomic organization between species cannot only help to refine tools to identify new miRNAs, but also provide insight into miRNA biogenesis and function.
\end{abstract}

\begin{abstract}
With the discovery of pervasive genome transcription (Carninci et al., 2005), it seems plausible that the abundant noncoding RNAs discovered thus far, both large and small, are only the beginning of vast numbers of regulatory RNAs. Perhaps the best characterized group of these newly discovered small noncoding RNAs are microRNAs (miRNAs), the first of which, lin-4, was discovered as a developmental timing regulator in Caenorhabditis elegans (Lee et al., 1993; Wightman et al., 1993). The development and use of high throughput sequencing techniques (Lu et al., 2005; Glazov et al., 2008) and the continuing refinement of computational prediction algorithms (Lai et al., 2003; Huang et al., 2007) are sure to increase the number of miRNAs identified. The most commonly used bioinformatics tool available for organizing these new and all other miRNAs is miRBase (http:// www.mirbase.org), an online database encompassing miRNA nomenclature, sequence information, annotation, and target prediction. As of this writing, miRBase, first developed and published in 2004, has grown to include 10,883 entries from vertebrates, insects, worms, plants, and viruses, discovered using direct cloning or bioinformatic prediction, and is a powerful tool for the study of miRNA genomics (Griffiths-Jones, 2004; Griffiths-Jones et al., 2006, 2008). The following is a short review of what is known regarding miRNAs in the context of the relationship of genomic organization to miRNA discovery and to understanding miRNA biogenesis and function across species.
\end{abstract}

(C) 2009 Wiley-Liss, Inc.

*Correspondence to: James G. Patton, Department of Biological Sciences, Vanderbilt University, Nashville, TN. james.g.patton@vanderbilt.edu. 


\section{microRNA Biogenesis and Function}

\section{miRNA biogenesis}

In order to properly relate the genomic organization of miRNAs to biogenesis and function, a basic overview of what is known regarding these two processes follows (Fig. 1). miRNAs are transcribed in the nucleus by RNA polymerase II and are $5^{\prime}$ capped and $3^{\prime}$ polyadenylated (Cai et al., 2004; Lee et al., 2004). Nascent transcripts are referred to as primary (pri-) miRNAs. Pri-miRNAs can be as long as several kilobases and contain one or more secondary structures primarily consisting of extended stem-loop structures (Lee et al., 2002). Regardless of whether the pri-mRNA transcripts are monocistronic or polycistronic, miRNA processing begins in the nucleus with cleavage at the stems by an RNase III-like enzyme, Drosha (Lee et al., 2002), which acts in concert with co-factors including DGCR8 (DiGeorge syndrome critical region 8, also known as Pasha in flies and nematodes) (Denli et al., 2004; Gregory et al., 2004; Han et al., 2004; Landthaler et al., 2004). Drosha and DGCR8 processing step occurs in what is referred to as the Microprocessor complex with processing occurring co-transcriptionally and preceding splicing for intron-encoded miRNAs (Kim and Kim, 2007; Morlando et al., 2008). In the special case of mirtrons, Drosha processing is unnecessary because the spliced intron itself corresponds exactly to a single, processed miRNA precursor (Okamura et al., 2007). After processing by Drosha or excision as a mirtron, the resulting $\sim 70$ nucleotide RNAs are referred to as precursor (pre-) miRNAs, which fold into mini-helical structures, allowing for recognition by Exportin 5 (Exp5), the nuclear export factor responsible for trafficking pre-miRNAs from the nucleus to the cytoplasm (Yi et al., 2003; Bohnsack et al., 2004; Lund et al., 2004).

Once in the cytoplasm, Dicer, another RNase III-like endonuclease, recognizes the premiRNA hairpin and cuts it at the loop end, creating a $\sim 22$ nt RNA duplex (Bernstein et al., 2001; Grishok et al., 2001; Hutvagner et al., 2001; Ketting et al., 2001; Knight and Bass, 2001). As with the Microprocesser, Dicer cleavage takes place in a larger complex including the human immunodeficiency virus transactivating response RNA-binding protein (TRBP or TARBP2, known as loquacious in Drosophila), which contains three dsRNA-binding domains and stabilizes the interaction of Dicer with the pre-miRNA (Chendrimada et al., 2005; Forstemann et al., 2005; Haase et al., 2005; Jiang et al., 2005; Saito et al., 2005). After Dicer cleavage, the resulting miRNA duplex is composed of the paired mature miRNA and its passenger strand, sometimes referred to as the miRNA* strand (Lau et al., 2001). The final step in miRNA biogenesis is the subsequent incorporation of the miRNA duplex into the RNA-induced silencing complex (RISC), the final effector complex. The exact details of assembly of this ribonucleoprotein complex are unclear; however, it is known that the duplex is loaded onto an Argonaute (Ago) protein, the core protein component of the RISC, while preserving the association with Dicer and TRBP (Schwarz et al., 2003). Once loaded, the miRNA strand, which is the strand that exhibits less stable base pairing at the $5^{\prime}$ end, remains associated with the Ago protein, while the passenger strand is degraded or unwound from the duplex (Mourelatos et al., 2002; Khvorova et al., 2003; Schwarz et al., 2003; Kawamata et al., 2009; Kim et al., 2009). 


\section{miRNA function}

Either as part of, or directly upon loading into the RISC complex, mature miRNAs are guided to their targets. Most often, miRNA-mRNA pairing in the $3^{\prime}$ UTR is imperfect which somehow facilitates translation repression, but exactly how and when in the translation process miRNAs mediate their effects is an area of great interest and continuing research (for review, see Filipowicz et al., 2008). In the limited number of cases where pairing is perfect, cleavage of the mRNA occurs (Hutvagner and Zamore, 2002). Four Ago proteins are encoded in the genomes of mammals and fish, but only Ago 2 has been shown in humans to be capable of "slicer" or cleavage activity of the mRNA target (Oates et al., 2000; Zhao et al., 2001; Hutvagner and Zamore, 2002; Martinez et al., 2002; Meister et al., 2004).

\section{miRNA Genomics}

\section{Genomics of let-7}

The first conserved miRNA, let-7, was found in a genetic screen in C. elegans (Reinhart et al., 2000). After its discovery as a developmental timing regulator in worms, BLASTN was used to identify genomic regions in the Drosophila melanogaster and human genomes with homology to let-7 precursors. Copies of let-7 were found in most metozoan species (Pasquinelli et al., 2000). The C. elegans genome encodes one copy of let-7, while most higher vertebrates have multiple copies. The zebrafish (Danio rerio) genome contains 10 let-7 family members, where a family describes miRNAs that all share the same "seed" region. "Seed" refers to nucleotides 2-7 from the 5 ' end of the miRNA and extensive pairing between the miRNA seed sequence and the mRNA is one of the main criteria used to identify mRNA targets (Brennecke et al., 2005). There are multiple copies of each let-7 family member encoded in the fish genome. The human genome encodes eight let-7 family members, as does the mouse genome; some of these miRNAs are present in multiple copies (Griffiths-Jones, 2006). The mapping of let-7 precursor sequences in similar genomic locations across multiple organisms provided initial insight into miRNA discovery using genomics. Also, the conservation of pre-let-7 sequences provided mechanistic insight into RNA sequences and structures required for the processing of pre-miRNAs to mature miRNAs.

\section{Using miRNA genomics to facilitate discovery}

Following the discovery of let-7, the task of cloning and sequencing small RNAs from various organisms was undertaken. Twenty-one human miRNAs were uncovered in total RNA from HeLa cells and 33 miRNAs from Drosophila were discovered (Lagos-Quintana et al., 2001). Interestingly, it was found that some of the miRNAs in these groups from both Drosophila and humans were encoded in the genome clustered with other miRNAs. In the case of the Drosophila miR-3/miR-6 cluster, which contains miRs-3, $-4,-5$, and three copies of $m i R-6$, the expression data for the miRNAs in the cluster is highly similar. This data were one of the first indications that miRNAs can be transcribed as long, polycistronic, primary transcripts (Fig. 3A). In an accompanying article, several new small miRNAs in C. elegans were also identified (Lau et al., 2001). Six of these miRNAs encoded by the miR-35-miR-41 cluster were shown to be similar in sequence and coordinately expressed, as were the 
miRNAs in four other clusters. However, it was also demonstrated that not all related miRNAs are found in clusters, using the example of the $m i R-42-44$ cluster, which has a homologous family member, $m i R-45$, encoded outside the cluster. At the same time, genomic comparisons of conserved intergenic regions from C. elegans and C. briggsae and the RNA folding algorithm "mfold" were used to predict 15 new miRNAs, which were then confirmed (Lee and Ambros, 2001). In these initial studies, the majority of miRNAs were found to be encoded in intergenic regions, implying the need for miRNA-specific promoters (Fig. 3A) (Lagos-Quintana et al., 2001; Lau et al., 2001; Lee and Ambros, 2001). That standard has shifted in the years that followed with the percentage of miRNAs in known transcription units (TUs) in mammalian genomes accounting for roughly half of the known miRNAs (Rodriguez et al., 2004). Thus far, this pattern has not always been observed in other species (Fig. 2) (Griffiths-Jones et al., 2008; Thatcher et al., 2008). A special subset of TU-associated miRNAs, intronic miRNAs, will be discussed in greater detail below, along with an explanation for the potential discrepancy between mammalian and teleost genomic organization.

\section{Genomics and understanding miRNA biogenesis}

Further evidence for miRNA clustering in the human genome was uncovered during examination of the proteins associated with miRNAs (Mourelatos et al., 2002). It was in seminal work from the Kim lab, however, that long primary transcripts corresponding to two miRNA clusters were found in total RNA from HeLa cells, providing the first experimental confirmation that miRNAs can be transcribed as polycistronic TUs (Lee et al., 2002). Using an in vitro processing system, it was shown that long primary transcripts could be processed into all the expected products from long primary, to medium length precursor, and finally, to mature, processed miRNAs. Following this work, genomic comparisons were coupled with tissue-specific cloning to find 37 novel miRNAs in human and mouse, seven of which were clustered with at least one other miRNA (Lagos-Quintana et al., 2003). New Drosophila miRNAs were also identified using computational analyses and cloning, some of which were found to reside in clusters (Aravin et al., 2003; Lai et al.,2003). It was not until the following year, however, that all these data converged for greater understanding of miRNA transcription. It was shown using the sequences of several miRNA clusters that RNA polymerase II transcribes the majority of miRNAs (Lee et al., 2004). In this same work, the promoter for the $m i R-23 a \sim 27 a \sim 24-2$ cluster was also identified, demonstrating that miRNAs can have cluster-specific promoters (Fig. 3A). This work was corroborated by data that showed that miRNAs are capped and polyadenylated, like other polymerase II transcripts (Cai et al., 2004).

\section{Structure of miRNA genes}

Complete definition of miRNA gene structure is ongoing. Characterization of a temporal regulatory element in the let-7 promoter in C. elegans (Johnson et al., 2003) and identification and biochemical confirmation of 59 putative promoters for 79 miRNAs in human cells (Fujita and Iba, 2008) have been reported. Putative promoters for most miRNA genes in four model species have been identified (Zhou et al., 2007). Additionally, polymerase II chromatin immunoprecipitation of regions surrounding known miRNA genes has revealed promoters for miRNAs that are up to several kb away (Corcoran et al., 2009). 
Analysis of transcription start sites, expressed sequence tag matches, $\mathrm{CpG}$ island predictions, $5^{\prime}$ and $3^{\prime}$ end identifiers, transcription factor binding sites, and polyadenylation signals were combined to analyze the structure of intergenic human miRNAs (Saini et al., 2007). Based on these analyses, it was discovered that the majority of intergenic human miRNAs have a primary transcript between 3 and $4 \mathrm{~kb}$ long, with a clearly delineated transcription start site and poly(A) signal serving as the boundaries of the RNA transcript. As more miRNA genes are discovered and mapped, it will be interesting to see whether the arrangements thus far observed are representative of only miRNAs or whether other transcript classes are detected. Either way, the additional information will help to shed light on overall miRNA genomic arrangement and biogenesis and also provide insight into the mechanisms that drive the exquisite patterns of tissue-specific expression observed for many miRNAs (Wienholds et al., 2005; Ason et al., 2006; Kapsimali et al., 2007).

\section{miRNA Genomic Organization and Function}

\section{Function of clustered miRNAs}

Somewhere between $36 \%$ and $47 \%$ of miRNAs are found in clusters in zebrafish, mouse, and human (Griffiths-Jones et al., 2008; Thatcher et al., 2008) (Fig. 2). Indeed, 55 and 51 distinct miRNA clusters exist in the human and mouse genomes, respectively (Yuan et al., 2009). Overexpression of the miR-17-92 cluster in mice results in proliferation as well as limited differentiation of lung epithelial progenitors (Hayashita et al., 2005; Lu et al., 2007). One confirmed target of the cluster is hypoxia-inducible factor-1 $\propto(H I F-1 \propto)$, which suggests the possibility of a regulatory circuit between $c-m y c, H I F-1 \propto$, and $m i R-17-92$ (Taguchi et al., 2008). This same cluster has also been shown to be overexpressed in B-cell lymphomas (Ota et al., 2004), and lung cancers (Hayashita et al., 2005), indicating that it acts as an oncogene. In contrast, the $m i R-15-16$ cluster is deleted in chronic lymphocytic leukemia indicating that it acts as a tumor suppressor (Calin et al., 2002). Aside from tumorigenesis, the mouse miR-183-96-182 cluster targets three components of the insulinsignaling pathway (Xu and Wong, 2008). What is striking about all of these clusters is that they frequently contain representatives from different miRNA families, meaning the miRNAs of a given cluster can target multiple different mRNAs. Based on analysis of protein interaction networks, it has been proposed that the mRNA transcripts coding for proteins that interact with each other are typically targeted by miRNAs from the same polycistronic cluster (Yuan et al., 2009). This finding is important because it implies extremely complex miRNA regulation of genetic networks and pathways and seems to indicate even more carefully nuanced regulation by miRNAs than was perhaps expected.

\section{miRNAs encoded within other transcription units}

A number of miRNA genes have also been discovered that reside within the TUs of other genes, both intronic and exonic (Lagos-Quintana et al., 2001, 2003; Lau et al., 2001; Lee et al., 2002). For example, human and mouse $m i R-186$ are found in the $2 \mathrm{~kb}$ intron 8 of zinc finger protein 5 (Lagos-Quintana et al., 2003). The $m i R-186$ precursor sequence (and its 50 flanking nucleotides) is the only highly conserved region of the intron, which facilitated its detection. This example illustrates production of a miRNA from the intronic RNA from a host gene (Fig. 3B). However, there are also examples of miRNA genes and clusters that 
reside within introns but are under the control of their own promoters, such as the miR-17-92 cluster (see above), which is found in intron 3 of the C13orf 25 gene (Ota et al., 2004). Initial analyses reported the existence of only a few miRNAs within the introns of other genes (Lagos-Quintana et al., 2001, 2003; Lau et al., 2001; Lee et al., 2002). Improving technology and refined mapping has raised the number of miRNAs located within other TUs to roughly $50 \%$ of all mammalian miRNAs (Rodriguez et al., 2004; Griffiths-Jones et al., 2008). These numbers vary, however, between species. Only about $13 \%$ of zebrafish miRNAs have so far been found to be associated with annotated TUs (Fig. 2) (Thatcher et al., 2008). It seems plausible, though, that this difference may be more a reflection of the incomplete annotation of the zebrafish genome rather than a true difference between teleost and mammalian genomic organization. As mentioned above and illustrated in Figure 2, the percentage of clustered miRNAs in mammalian and teleost genomes are similar. This observation could suggest that the general genomic organization is similar and that as zebrafish genomic annotation continues to improve, the number of miRNAs found to be associated with known TUs will increase to levels found in mammalian genomes.

miRNAs associated with annotated transcripts can be intronic, exonic, or a combination (Fig. 3B,C). A search of CoGemiR (http://cogemir.tigem.it/htdocs/index.html) for exonic human miRNAs revealed only 24 out of $\sim 700$ human miRNAs to be located within the exons of annotated genes, usually noncoding transcripts (Maselli et al., 2008). Intronic miRNAs in the sense orientation within host genes are more common and better studied. Coordinate expression of intronic miRNAs within host genes has been widely observed (Baskerville and Bartel, 2005; Wang et al., 2009). These miRNAs can be located within the introns of protein coding genes or within long noncoding RNAs. They can also be classified into novel families based on the identity of their host genes (Rodriguez et al., 2004). An interesting pair is the example of $m i R-148 b$ and $m i R-152$, which share the same seed. These miRNAs are encoded in the introns of different genes, each gene encoding a subunit of the coatomer transporter (Rodriguez et al., 2004). miRNAs with unrelated sequences have also been found encoded within the introns of related proteins. Intronic miRNAs in mouse and human are most often found in large introns toward the $5^{\prime}$ end of the host gene (Zhou and Lin, 2008). Intronic miRNAs that are coordinately expressed with their host genes also introduce the possibility of feedback loops, both negative and positive, within a single TU. For example, $m i R-208$, a heart-specific miRNA, is encoded in intron 27 of human and mouse $\propto M H C$ and regulates a transcription factor that can act as a negative regulator of $\beta M H C$ in response to stress in the heart (van Rooij et al., 2007). Similarly, $m i R-338$ is encoded in the intron of the apoptosis-associated tyrosine kinase (AATK), which is necessary for neuronal differentiation, and transcriptionally represses a group of genes that negatively regulate neuronal differentiation in human cell culture (Barik, 2008). These examples demonstrate the complex levels of regulation that are possible with miRNAs, especially those encoded in introns of protein-coding genes. It is reasonable to expect that many more examples of this type of elegant regulation will become apparent with continued research. 
miRNAs associated with Hox gene clusters

A special case of genomic organization related to miRNA evolution and function are the miRNAs associated with Hox gene clusters in vertebrates. Hox genes are homeodomaincontaining transcription factors involved in patterning during development that are spatially clustered and temporally expressed in the genomes of metazoans (McGinnis and Krumlauf, 1992). Mammalian genomes have four Hox gene clusters, denoted A, B, C, D (Wagner et al., 2003), while teleost genomes have undergone an additional duplication but have lost one cluster, and so contain seven Hox gene clusters, denoted Aa, Bb, Cc, etc. (Amores et al., 1998). In vertebrate genomes, $m i R-10$ sequences are found between Hox 5 and Hox4, while miR-196 sequences are found between Hox10 and Hox9. The evolution of each of these Hox-associated miRNAs closely resembles that of the Hox clusters themselves, which suggests functional significance. One copy of $m i R-196, m i R-196-A$ is located in the $5^{\prime}$ UTR of HoxA9 transcripts in human, mouse, pig, and chicken. HoxA9 mRNA is known to undergo extensive splicing, which appears to be required for the production of both mature miR-196-A and HoxA9 protein (Tanzer et al., 2005). Interestingly, it has been shown in teleosts that all that remains of the lost Hox cluster, $H o x D b$, is $m i R-10$ (Woltering and Durston, 2006). Functionally, $m i R-10$ has been shown in fish to repress translation of HoxBIa and HoxB3a, both of which are nearby in the genome (Woltering and Durston, 2008). The MREs in the $3^{\prime}$ UTRs of HoxBI and HoxB3 are largely conserved from teleost to human, so it is likely that regulation of $H o x$ genes by $m i R-10$ is also conserved. The functional link between miR-196 family members and Hox genes was uncovered when it was shown that a MRE in the $3^{\prime}$ UTR of HoxB8 is a nearly perfect match for miR-196 (Yekta et al., 2004). Further, miR-196 has strong target sites in three other Hox genes and was shown to facilitate cleavage of $H o x B 8$ mRNAs in mouse. Together, the proteins and miRNAs encoded within the Hox cluster beautifully illustrate the potential for coevolutionary conservation of intricate feedback regulatory loops.

\section{Function of abundant miRNAs}

The relationship between genomic abundance and function of a miRNA is worth noting. Evolutionarily, one might expect more copies of miRNAs that are essential for regulating crucial decisions and events. Perhaps the best example of an abundant miRNA family carrying out such an essential function is illustrated by the $m i R-430$ family in zebrafish. The $m i R-430$ family is by far the most abundant miRNA family in zebrafish, with five family members present in over 90 clustered copies in the genome (Thatcher et al., 2008). The $m i R-430$ family has been shown to promote deadenylation and clearance of maternal mRNAs at the onset of zygotic transcription during zebrafish development. Most fish maternal mRNAs contain target sites complementary to miR-430 and maternal zygotic Dicer mutants maintain high levels of maternal transcripts leading to aberrant development. Remarkably, the defects can be rescued by resupplying just miR-430 (Giraldezet al., 2006). Copy number in the genome also relates to expression levels, as high throughput sequencing of zebrafish embryos reveals that miR-430 family members represent $70 \%$ of the total miRNA transcripts at the onset of zygotic transcription (Wei and Patton, unpublished work). In medaka (Oryzias latipes), a distantly related teleost, $m i R-430$ is not as abundant as in zebrafish; however, the $m i R-430$ family displays a conserved role in early embryogenesis. 
Interestingly, the miR-430 family members in medaka are located on chromosome 4 , which is also where the majority of zebrafish $m i R-430$ family members are encoded (Thatcher et al., 2008; Tani et al., 2009). The difference in abundance between these two distantly related species may indicate an increased importance for the miR-430 in zebrafish related to the levels of maternal transcripts, but the positional and functional conservation nonetheless demonstrates importance in both species.

\section{Conclusions}

Genomic location and context of miRNAs can be helpful in determining information about the biogenesis and function of specific miRNAs and miRNAs in general. By examining the genomic location and surrounding sequences flanking miRNAs, more and more knowledge about specific promoter elements driving transcription will be gained. This should in turn help to identify new miRNAs. When coupled to refined genomic analyses using deep sequencing, it seems likely that the complete set of miRNA will be identified which can then be expanded to look for other classes of noncoding RNAs (Lu et al., 2005; Glazov et al., 2008). The thorough and ongoing study of miRNA genes has revealed possibilities for genome organization that might not have been uncovered if not for the discovery of miRNAs. The available information relating genomic organization of miRNA genes to their function will also be helpful when evaluating the function of yet to be discovered miRNAs and other noncoding RNA genes. The discovery of miRNAs has opened a world of possibilities in gene regulation not imagined before. If miRNAs are just a subclass of small RNAs, future discoveries of noncoding RNAs may reveal even more amazing possibilities for overall gene regulation.

\section{Acknowledgments}

This work was supported by a grant from the NIH (GM 075790) to J.G.P. A.F.O. was supported by the Vanderbilt University Program in Developmental Biology (NICHD grant 007502).

Contract grant sponsor: NIH;

Contract grant number: GM 075790.

\section{Literature Cited}

Amores A, Force A, Yan YL, Joly L, Amemiya C, Fritz A, Ho RK, Langeland J, Prince V, Wang YL, Westerfield M, Ekker M, Postlethwait JH. Zebrafish hox clusters and vertebrate genome evolution. Science. 1998; 282:1711-1714. [PubMed: 9831563]

Aravin AA, Lagos-Quintana M, Yalcin A, Zavolan M, Marks D, Snyder B, Gaasterland T, Meyer J, Tuschl T. The small RNA profile during Drosophila melanogaster development. Dev Cell. 2003; 5:337-350. [PubMed: 12919683]

Ason B, Darnell DK, Wittbrodt B, Berezikov E, Kloosterman WP, Wittbrodt J, Antin PB, Plasterk RHA. Differences in vertebrate microRNA expression. Proc Natl Acad Sci USA. 2006; 103:1438514389. [PubMed: 16983084]

Barik S. An intronic microRNA silences genes that are functionally antagonistic to its host gene. Nucleic Acids Res. 2008; 36:5232-5241. [PubMed: 18684991]

Baskerville S, Bartel DP. Microarray profiling of microRNAs reveals frequent coexpression with neighboring miRNAs and host genes. RNA. 2005; 11:241-247. [PubMed: 15701730] 
Bernstein E, Caudy A, Hammond S, Hannon G. Role for a bidentate ribonuclease in the initiation step of RNA interference. Nature. 2001; 409:363-366. [PubMed: 11201747]

Bohnsack MT, Czaplinski K, Gorlich D. Exportin 5 is a RanGTP-dependent dsRNA-binding protein that mediates nuclear export of pre-miRNAs. RNA. 2004; 10:185-191. [PubMed: 14730017]

Brennecke J, Stark A, Russell RB, Cohen SM. Principles of microRNA-target recognition. PLoS Biol. 2005; 3:e85. [PubMed: 15723116]

Cai X, Hagedorn CH, Cullen BR. Human microRNAs are processed from capped, polyadenylated transcripts that can also function as mRNAs. RNA. 2004; 10:1957-1966. [PubMed: 15525708]

Calin GA, Dumitru CD, Shimizu M, Bichi R, Zupo S, Noch E, Aldler H, Rattan S, Keating M, Rai K, Rassenti L, Kipps T, Negrini M, Bullrich F, Croce CM. Frequent deletions and down-regulation of micro- RNA genes miR15 and miR16 at 13q14 in chronic lymphocytic leukemia. Proc Natl Acad Sci USA. 2002; 99:15524-15529. [PubMed: 12434020]

Carninci P, Kasukawa T, Katayama S, Gough J, Frith MC, Maeda N, Oyama R, Ravasi T, Lenhard B, Wells C, Kodzius R, Shimokawa K, Bajic VB, Brenner SE, Batalov S, Forrest ARR, Zavolan M, Davis MJ, Wilming LG, Aidinis V, Allen JE, Ambesi-Impiombato A, Apweiler R, Aturaliya RN, Bailey TL, Bansal M, Baxter L, Beisel KW, Bersano T, Bono H, Chalk AM, Chiu KP, Choudhary V, Christoffels A, Clutterbuck DR, Crowe ML, Dalla E, Dalrymple BP, de Bono B, Della Gatta G, di Bernardo D, Down T, Engstrom P, Fagiolini M, Faulkner G, Fletcher CF, Fukushima T, Furuno M, Futaki S, Gariboldi M, Georgii-Hemming P, Gingeras TR, Gojobori T, Green RE, Gustincich S, Harbers M, Hayashi Y, Hensch TK, Hirokawa N, Hill D, Huminiecki L, Iacono M, Ikeo K, Iwama A, Ishikawa T, Jakt M, Kanapin A, Katoh M, Kawasawa Y, Kelso J, Kitamura H, Kitano H, Kollias G, Krishnan SPT, Kruger A, Kummerfeld SK, Kurochkin IV, Lareau LF, Lazarevic D, Lipovich L, Liu J, Liuni S, McWilliam S, Madan Babu M, Madera M, Marchionni L, Matsuda H, Matsuzawa S, Miki H, Mignone F, Miyake S, Morris K, Mottagui-Tabar S, Mulder N, Nakano N, Nakauchi H, Ng P, Nilsson R, Nishiguchi S, Nishikawa S, Nori F, Ohara O, Okazaki Y, Orlando V, Pang KC, Pavan WJ, Pavesi G, Pesole G, Petrovsky N, Piazza S, Reed J, Reid JF, Ring BZ, Ringwald M, Rost B, Ruan Y, Salzberg SL, Sandelin A, Schneider C, Schonbach C, Sekiguchi K, Semple CAM, Seno S, Sessa L, Sheng Y, Shibata Y, Shimada H, Shimada K, Silva D, Sinclair B, Sperling S, Stupka E, Sugiura K, Sultana R, Takenaka Y, Taki K, Tammoja K, Tan SL, Tang S, Taylor MS, Tegner J, Teichmann SA, Ueda HR, van Nimwegen E, Verardo R, Wei CL, Yagi K, Yamanishi H, Zabarovsky E, Zhu S, Zimmer A, Hide W, Bult C, Grimmond SM, Teasdale RD, Liu ET, Brusic V, Quackenbush J, Wahlestedt C, Mattick JS, Hume DA, Kai C, Sasaki D, Tomaru Y, Fukuda S, Kanamori-Katayama M, Suzuki M, Aoki J, Arakawa T, Iida J, Imamura K, Itoh M, Kato T, Kawaji H, Kawagashira N, Kawashima T, Kojima M, Kondo S, Konno H, Nakano K, Ninomiya N, Nishio T, Okada M, Plessy C, Shibata K, Shiraki T, Suzuki S, Tagami M, Waki K, Watahiki A, Okamura-Oho Y, Suzuki H, Kawai J, Hayashizaki Y. The transcriptional landscape of the mammalian genome. Science. 2005; 309:1559-1563. [PubMed: 16141072]

Chendrimada T, Gregory R, Kumaraswamy E, Norman J, Cooch N, Nishikura K, Shiekhattar R. TRBP recruits the Dicer complex to Ago2 for microRNA processing and gene silencing. Nature. 2005; 436:740-744. [PubMed: 15973356]

Corcoran DL, Pandit KV, Gordon B, Bhattacharjee A, Kaminski N, Benos PV. Features of mammalian microRNA promoters emerge from polymerase II chromatin immunoprecipitation data. PLoS One. 2009; 4:e5279. [PubMed: 19390574]

Denli AM, Tops BB, Plasterk RH, Ketting RF, Hannon GJ. Processing of primary microRNAs by the microprocessor complex. Nature. 2004; 432:231-235. [PubMed: 15531879]

Filipowicz W, Bhattacharyya S, Sonenberg N. Mechanisms of post-transcriptional regulation by microRNAs: Are the answers in sight? Nat Rev Genet. 2008; 2008:102-114. [PubMed: 18197166]

Forstemann K, Tomari Y, Du T, Vagin VV, Denli AM, Bratu DP, Klattenhoff C, Theurkauf WE, Zamore PD. Normal microRNA maturation and germ-line stem cell maintenance requires Loquacious, a double-stranded RNA-binding domain protein. PLoS Biol. 2005; 3:e236. [PubMed: 15918770]

Fujita S, Iba H. Putative promoter regions of miRNA genes involved in evolutionary conserved regulatory systems among vertebrates. Bioinformatics. 2008; 24:303-308. [PubMed: 18055479] 
Giraldez AJ, Mishima Y, Rihel J, Grocock RJ, van Dongen S, Inoue K, Enright AJ, Schier AF. Zebrafish MiR-430 promotes deadenylation and clearance of maternal mRNAs. Science. 2006; 312:75-79. [PubMed: 16484454]

Glazov EA, Cottee PA, Barris WC, Moore RJ, Dalrymple BP, Tizard ML. A microRNA catalog of the developing chicken embryo identified by a deep sequencing approach. Genome Res. 2008; 18:957-964. [PubMed: 18469162]

Gregory RI, Yan KP, Amuthan G, Chendrimada T, Doratotaj B, Cooch N, Shiekhattar R. The Microprocessor complex mediates the genesis of microRNAs. Nature. 2004; 432:235-240. [PubMed: 15531877]

Griffiths-Jones S. The microRNA registry. Nucleic Acids Res. 2004; 32:D109-D111. [PubMed: 14681370]

Griffiths-Jones S. miRBase: The microRNA sequence database. Methods Mol Biol. 2006; 342:129_ 138. [PubMed: 16957372]

Griffiths-Jones S, Grocock RJ, van Dongen S, Bateman A, Enright AJ. miRBase: microRNA sequences, targets and gene nomenclature. Nucleic Acids Res. 2006; 34:D140-D144. [PubMed: 16381832]

Griffiths-Jones S, Saini HK, van Dongen S, Enright AJ. miRBase: Tools for microRNA genomics. Nucleic Acids Res. 2008; 36:D154-D158. [PubMed: 17991681]

Grishok A, Pasquinelli AE, Conte D, Li N, Parrish S, Ha I, Baillie DL, Fire A, Ruvkun G, Mello CC. Genes and mechanisms related to RNA interference regulate expression of the small temporal RNAs that control C. elegans developmental timing. Cell. 2001; 106:23-34. [PubMed: 11461699]

Haase AD, Jaskiewicz L, Zhang H, Lainé S, Sack R, Gatignol A, Filipowicz W. TRBP, a regulator of cellular PKR and HIV-1 virus expression, interacts with Dicer and functions in RNA silencing. EMBO Rep. 2005; 6:961-967. [PubMed: 16142218]

Han J, Lee Y, Yeom KH, Kim YK, Jin H, Kim VN. The Drosha-DGCR8 complex in primary microRNA processing. Genes Dev. 2004; 18:3016-3027. [PubMed: 15574589]

Hayashita Y, Osada H, Tatematsu Y, Yamada H, Yanagisawa K, Tomida S, Yatabe Y, Kawahara K, Sekido Y, Takahashi T. A polycistronic microRNA cluster, miR-17-92, is overexpressed in human lung cancers and enhances cell proliferation. Cancer Res. 2005; 65:9628-9632. [PubMed: 16266980]

Huang TH, Fan B, Rothschild MF, Hu ZL, Li K, Zhao SH. MiRFinder: An improved approach and software implementation for genome-wide fast microRNA precursor scans. BMC Bioinformatics. 2007; 8:341. [PubMed: 17868480]

Hutvagner G, Zamore PD. A microRNA in a multiple-turnover RNAi enzyme complex. Science. 2002; 297:2056-2060. [PubMed: 12154197]

Hutvagner G, McLachlan J, Pasquinelli AE, Balint E, Tuschl T, Zamore PD. A cellular function for the RNA-interference enzyme Dicer in the maturation of the let-7 small temporal RNA. Science. 2001; 293:834-838. [PubMed: 11452083]

Jiang F, Ye X, Liu X, Fincher L, McKearin D, Liu Q. Dicer-1 and R3D1-L catalyze microRNA maturation in Drosophila. Genes Dev. 2005; 19:1674-1679. [PubMed: 15985611]

Johnson SM, Lin SY, Slack FJ. The time of appearance of the C. elegans let-7 microRNA is transcriptionally controlled utilizing a temporal regulatory element in its promoter. Dev Biol. 2003; 259:364-379. [PubMed: 12871707]

Kapsimali M, Kloosterman WP, de Bruijn E, Rosa F, Plasterk RH, Wilson SW. MicroRNAs show a wide diversity of expression profiles in the developing and mature central nervous system. Genome Biol. 2007; 8:R173. [PubMed: 17711588]

Kawamata T, Seitz H, Tomari Y. Structural determinants of miRNAs for RISC loading and slicerindependent unwinding. Nat Struct Mol Biol. 2009; 16:953-960. [PubMed: 19684602]

Ketting RF, Fischer SE, Bernstein E, Sijen T, Hannon GJ, Plasterk RH. Dicer functions in RNA interference and in synthesis of small RNA involved in developmental timing in C. elegans. Genes Dev. 2001; 15:2654-2659. [PubMed: 11641272]

Khvorova A, Reynolds A, Jayasena SD. Functional siRNAs and miRNAs exhibit strand bias. Cell. 2003; 115:209-216. [PubMed: 14567918] 
Kim YK, Kim VN. Processing of intronic microRNAs. EMBO J. 2007; 26:775-783. [PubMed: 17255951]

Kim V, Han J, Siomi M. Biogenesis of small RNAs in animals. Nat Rev Mol Cell Biol. 2009; 10:126139. [PubMed: 19165215]

Knight SW, Bass BL. A role for the RNase III enzyme DCR-1 in RNA interference and germ line development in Caenorhabditis elegans. Science. 2001; 293:2269-2271. [PubMed: 11486053]

Lagos-Quintana M, Rauhut R, Lendeckel W, Tuschl T. Identification of novel genes coding for small expressed RNAs. Science. 2001; 294:853-858. [PubMed: 11679670]

Lagos-Quintana M, Rauhut R, Meyer J, Borkhardt A, Tuschl T. New microRNAs from mouse and human. RNA. 2003; 9:175-179. [PubMed: 12554859]

Lai EC, Tomancak P, Williams RW, Rubin GM. Computational identification of Drosophila microRNA genes. Genome Biol. 2003; 4:R42. [PubMed: 12844358]

Landthaler M, Yalcin A, Tuschl T. The human DiGeorge syndrome critical region gene 8 and Its $D$. melanogaster homolog are required for miRNA biogenesis. Curr Biol. 2004; 14:2162-2167. [PubMed: 15589161]

Lau NC, Lim LP, Weinstein EG, Bartel DP. An abundant class of tiny RNAs with probable regulatory roles in Caenorhabditis elegans. Science. 2001; 294:858-862. [PubMed: 11679671]

Lee RC, Ambros V. An extensive class of small RNAs in Caenorhabditis elegans. Science. 2001; 294:862-864. [PubMed: 11679672]

Lee RC, Feinbaum RL, Ambros V. The C. elegans heterochronic gene lin-4 encodes small RNAs with antisense complementarity to lin-14. Cell. 1993; 75:843-854. [PubMed: 8252621]

Lee Y, Jeon K, Lee JT, Kim S, Kim VN. MicroRNA maturation: Stepwise processing and subcellular localization. EMBO J. 2002; 21:4663-4670. [PubMed: 12198168]

Lee Y, Kim M, Han J, Yeom KH, Lee S, Baek SH, Kim VN. MicroRNA genes are transcribed by RNA polymerase II. EMBO J. 2004; 23:4051-4060. [PubMed: 15372072]

Lu C, Tej SS, Luo S, Haudenschild CD, Meyers B, Green P. Elucidation of the small RNA component of the transcriptome. Science. 2005; 309:1567-1569. [PubMed: 16141074]

Lu Y, Thomson JM, Wong HY, Hammond SM, Hogan BL. Transgenic over-expression of the microRNA miR-17-92 cluster promotes proliferation and inhibits differentiation of lung epithelial progenitor cells. Dev Biol. 2007; 310:442-453. [PubMed: 17765889]

Lund E, Guttinger S, Calado A, Dahlberg JE, Kutay U. Nuclear export of microRNA precursors. Science. 2004; 303:95-98. [PubMed: 14631048]

Martinez J, Patkaniowska A, Urlaub H, Luhrman R, Tuschl T. Single-stranded antisense siRNAs guide target RNA cleavage in RNAi. Cell. 2002; 110:563-574. [PubMed: 12230974]

Maselli V, Di Bernardo D, Banfi S. CoGemiR: A comparative genomics microRNA database. BMC Genomics. 2008; 9:457. [PubMed: 18837977]

McGinnis W, Krumlauf R. Homeobox genes and axial patterning. Cell. 1992; 68:283-302. [PubMed: 1346368]

Meister G, Landthaler M, Patkaniowska A, Dorsett Y, Teng G, Tuschl T. Human Argonaute2 mediates RNA cleavage targeted by miRNAs and siRNAs. Mol Cell. 2004; 15:185-197. [PubMed: 15260970]

Morlando M, Ballarino M, Gromak N, Pagano F, Bozzoni I, Proudfoot NJ. Primary microRNA transcripts are processed co-transcriptionally. Nat Struct Mol Biol. 2008; 15:902-909. [PubMed: 19172742]

Mourelatos Z, Dostie J, Paushkin S, Sharma A, Charroux B, Abel L, Rappsilber J, Mann M, Dreyfuss G. miRNPs: A novel class of ribonucleoproteins containing numerous microRNAs. Genes Dev. 2002; 16:720-728. [PubMed: 11914277]

Oates AC, Bruce AEE, Ho RK. Too much interference: Injection of double-stranded rna has nonspecific effects in the zebrafish embryo. Dev Biol. 2000; 224:20. [PubMed: 10898958]

Okamura K, Hagen JW, Duan H, Tyler DM, Lai E. The mirtron pathway generates microRNA-class regulatory RNAs in Drosophila. Cell. 2007; 130:89-100. [PubMed: 17599402] 
Ota A, Tagawa H, Karnan S, Tsuzuki S, Karpas A, Kira S, Yoshida Y, Seto M. Identification and characterization of a novel gene, C13orf25, as a target for 13q31-q32 amplification in malignant lymphoma. Cancer Res. 2004; 64:3087-3095. [PubMed: 15126345]

Pasquinelli AE, Reinhart BJ, Slack FJ, Martindale MQ, Kuroda MI, Maller B, Hayward DC, Ball EE, Degnan B, Müller P, Spring J, Srinivasan A, Fishman M, Finnerty J, Corbo J, Levine M, Leahy P, Davidson E, Ruvkun G. Conservation of the sequence and temporal expression of let-7 heterochronic regulatory RNA. Nature. 2000; 408:86-89. [PubMed: 11081512]

Reinhart BJ, Slack FJ, Basson M, Pasquinelli AE, Bettinger JC, Rougvie AE, Horvitz HR, Ruvkun G. The 21-nucleotide let-7 RNA regulates developmental timing in Caenorhabditis elegans. Nature. 2000; 403:901-906. [PubMed: 10706289]

Rodriguez A, Griffiths-Jones S, Ashurst JL, Bradley A. Identification of mammalian microRNA host genes and transcription units. Genome Res. 2004; 14:1902-1910. [PubMed: 15364901]

Saini HK, Griffiths-Jones S, Enright AJ. Genomic analysis of human microRNA transcripts. Proc Natl Acad Sci USA. 2007; 104:17719-17724. [PubMed: 17965236]

Saito K, Ishizuka A, Siomi H, Siomi MC. Processing of pre-microRNAs by the Dicer-1-Loquacious complex in Drosophila cells. PLoS Biol. 2005; 3:e235. [PubMed: 15918769]

Schwarz DS, Hutvagner G, Du T, Xu Z, Aronin N, Zamore PD. Asymmetry in the assembly of the RNAi enzyme complex. Cell. 2003; 115:199-208. [PubMed: 14567917]

Taguchi A, Yanagisawa K, Tanaka M, Cao K, Matsuyama Y, Goto H, Takahashi T. Identification of hypoxia-inducible factor-1 alpha as a novel target for miR-17-92 microRNA cluster. Cancer Res. 2008; 68:5540-5545. [PubMed: 18632605]

Tani S, Kusakabe R, Naruse K, Sakamoto H, Inoue K. Genomic organization and embryonic expression of miR-430 in medaka (Oryzias latipes): Insights into the post-transcriptional gene regulation in early development. Gene. 2009; 449:41-49. [PubMed: 19770025]

Tanzer A, Amemiya CT, Kim CB, Stadler PF. Evolution of microRNAs located within Hox gene clusters. J Exp Zool B Mol Dev Evol. 2005; 304:75-85. [PubMed: 15643628]

Thatcher E, Bond J, Paydar I, Patton J. Genomic organization of zebrafish microRNAs. BMC Genomics. 2008; 9:253. [PubMed: 18510755]

van Rooij E, Sutherland LB, Qi X, Richardson JA, Hill J, Olson EN. Control of stress-dependent cardiac growth and gene expression by a microRNA. Science. 2007; 316:575-579. [PubMed: 17379774]

Wagner GP, Amemiya C, Ruddle F. Hox cluster duplications and the opportunity for evolutionary novelties. Proc Natl Acad Sci USA. 2003; 100:14603-14606. [PubMed: 14638945]

Wang D, Lu M, Miao J, Li T, Wang E, Cui Q. Cepred: Predicting the co-expression patterns of the human intronic microRNAs with their host genes. PLoS One. 2009; 4:e4421. [PubMed: 19204784]

Wienholds E, Kloosterman WP, Miska E, Alvarez-Saavedra E, Berezikov E, de Bruijn E, Horvitz HR, Kauppinen S, Plasterk RHA. MicroRNA expression in zebrafish embryonic development. Science. 2005; 309:310-311. [PubMed: 15919954]

Wightman B, Ha I, Ruvkun G. Posttranscriptional regulation of the heterochronic gene lin-14 by lin-4 mediates temporal pattern formation in C. elegans. Cell. 1993; 75:855-862. [PubMed: 8252622]

Woltering JM, Durston AJ. The zebrafish hoxDb cluster has been reduced to a single microRNA. Nat Genet. 2006; 38:601-602. [PubMed: 16736008]

Woltering JM, Durston AJ. MiR-10 represses HoxB1a and HoxB3a in zebrafish. PLoS One. 2008; 3:e1396. [PubMed: 18167555]

$\mathrm{Xu}$ J, Wong C. A computational screen for mouse signaling pathways targeted by microRNA clusters. RNA. 2008; 14:1276-1283. [PubMed: 18511500]

Yekta S, Shih IH, Bartel DP. MicroRNA-directed cleavage of HOXB8 mRNA. Science. 2004; 304:594-596. [PubMed: 15105502]

Yi R, Qin Y, Macara IG, Cullen BR. Exportin-5 mediates the nuclear export of pre-microRNAs and short hairpin RNAs. Genes Dev. 2003; 17:3011-3016. [PubMed: 14681208]

Yuan X, Liu C, Yang P, He S, Liao Q, Kang S, Zhao Y. Clustered microRNAs' coordination in regulating protein-protein interaction network. BMC Syst Biol. 2009; 3:65. [PubMed: 19558649] 
Zhao Z, Cao Y, Li M, Meng A. Double-stranded RNA injection produces nonspecific defects in zebrafish. Dev Biol. 2001; 229:215. [PubMed: 11133165]

Zhou H, Lin K. Excess of microRNAs in large and very $5^{\prime}$ biased introns. Biochem Biophys Res Commun. 2008; 368:709-715. [PubMed: 18249189]

Zhou X, Ruan J, Wang G, Zhang W. Characterization and identification of microRNA core promoters in four model species. PLoS Comput Biol. 2007; 3:e37. [PubMed: 17352530] 


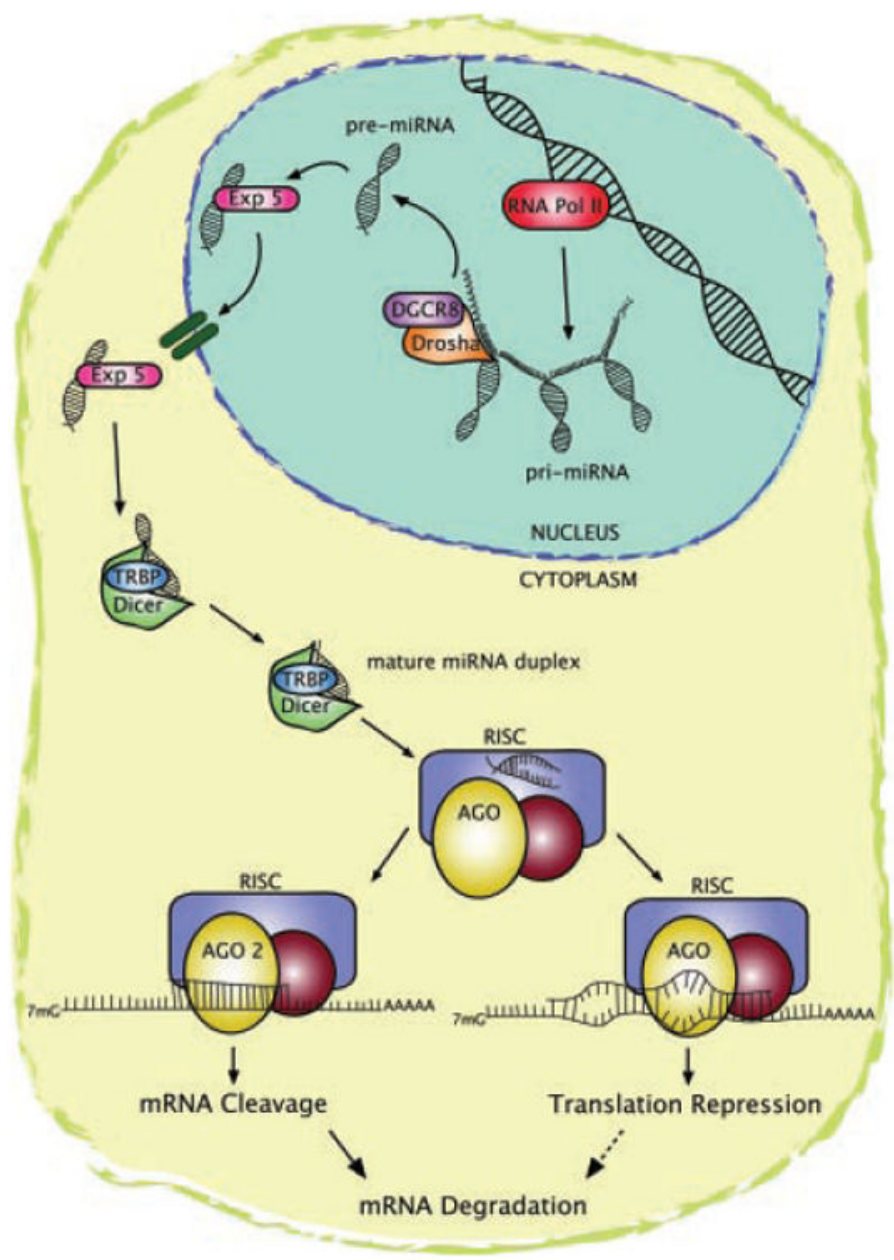

Fig. 1.

miRNA Biogenesis. miRNAs are transcribed by RNA polymerase II as long primary transcripts (pri-miRNA), which are processed in the nucleus into $\sim 70 \mathrm{nt}$ hairpins (premiRNA) by Drosha, an RNAse-III like enzyme acting with DGCR8 and other co-factors. Export from the nucleus is via GTP-dependent Exportin 5. In the cytoplasm, a second RNAse-III like enzyme, Dicer, cleaves the pre-miRNA into a mature dsRNA duplex. One strand of the 21-23 nucleotide dsRNA is packaged into the RISC and guided to target mRNAs, while the other is unwound and degraded. Pairing between miRNAs and target mRNAs takes place in association with one or more Argonaute proteins, the major protein component of RISCs. Depending upon the degree of complementarity between the mRNA and the miRNA, the mRNA is either subject to repression of translation or cleavage and degradation. [Color figure can be viewed in the online issue, which is available at www.interscience.wiley.com.] 


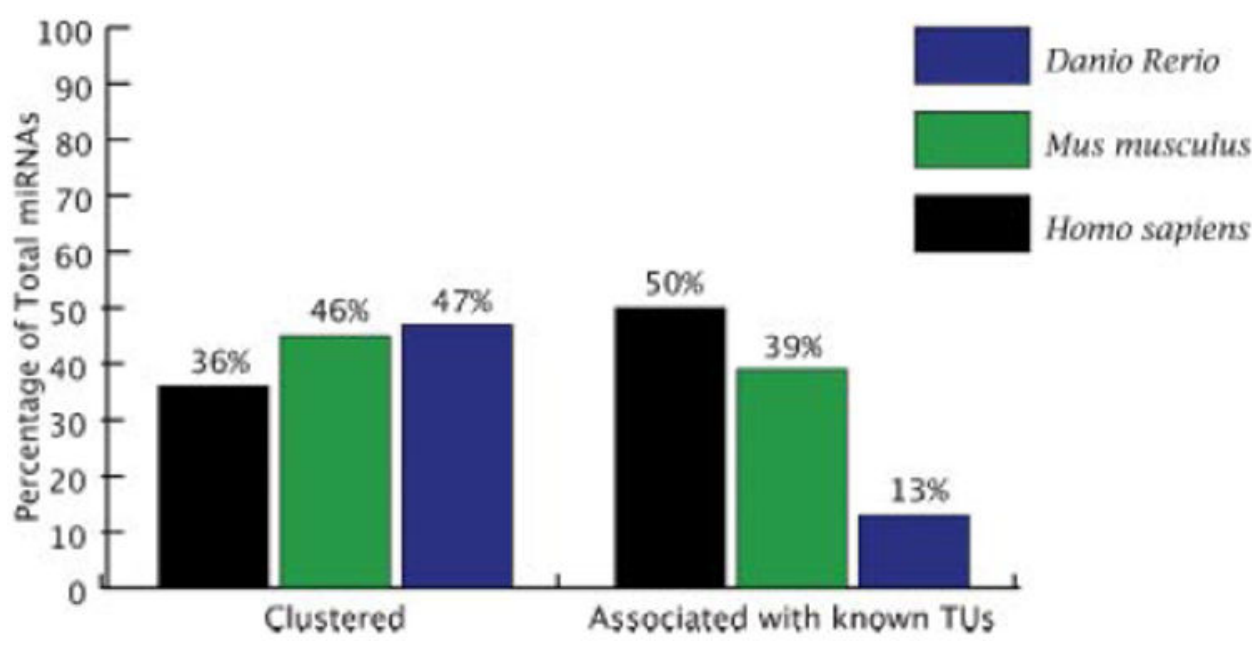

Fig. 2.

Genomic distribution of miRNAs. Zebrafish (Danio rerio) are represented by blue bars, mouse (Mus musculus) by green bars, and humans (Homo sapiens) by black bars. The percentage of miRNAs encoded within clusters with the potential to be transcribed as single polycistronic primary transcripts is represented by the first set of bars. The percentage of miRNAs associated with known transcription units (TUs) is represented by the second set of bars (Griffiths-Jones et al., 2008; Thatcher et al., 2008). [Color figure can be viewed in the online issue, which is available at www.interscience.wiley.com.] 


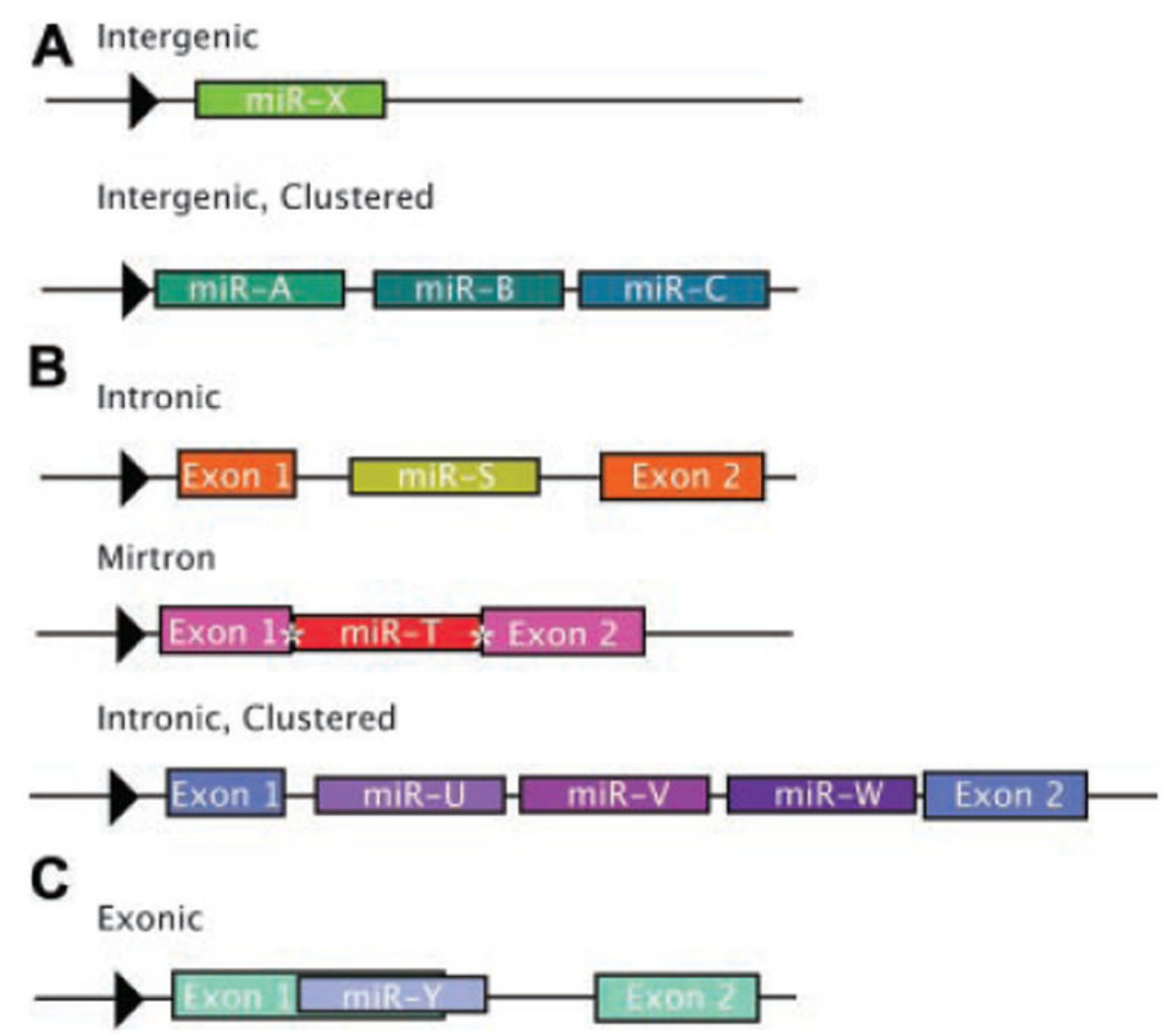

Fig. 3.

Genomic location of miRNAs. A: Intergenic miRNAs are found in genomic regions distinct from known transcription units. These miRNAs can be monocistronic (top part) with their own promoters (black arrowhead), or polycistronic, where several miRNAs are transcribed as cluster of primary transcripts (bottom part) with a shared promoter (black arrowhead). B: Intronic miRNAs are found in the introns of annotated genes, both protein coding and noncoding. These miRNAs can be present as a single miRNA (top part) or as a cluster of several miRNAs (bottom part). Intronic miRNAs are thought to be transcribed from the same promoter as their host genes (black arrowhead, all parts) and processed from the introns of host gene transcripts. In the special case of mirtrons (middle part), the intron is the exact sequence of the pre-miRNA with splice sites on either side (denoted by white asterisks). In this case, the Microprocessor complex is thought to be unnecessary in mirtron maturation (Okamura et al., 2007). C: Exonic miRNAs are far more rare than either of the types above and often overlap an exon and an intron of a noncoding gene. These miRNAs are also thought to be transcribed by their host gene promoter and their maturation often excludes host gene function (Rodriguez et al., 2004). [Color figure can be viewed in the online issue, which is available at www.interscience.wiley.com.] 